\title{
Influence of Green Synthesized Zinc Oxide Nanoparticles on Seed Germination and Seedling Growth in Wheat (Triticum aestivum)
}

\author{
Bhupendra Bhaskar Meher ${ }^{1}$, Shivraj Sahu ${ }^{1}$, Shivangi Singhal ${ }^{1}$, \\ Mayank Joshi ${ }^{1}$, Poonam Maan ${ }^{2}$ and Sneh Gautam ${ }^{1} *$ \\ ${ }^{1}$ Department of Molecular Biology \& Genetic Engineering, G.B.Pant University of \\ Agriculture \& Technology, Pantnagar-263145, Uttarakhand, India \\ ${ }^{2}$ Department of Agriculture Biotechnology, S.V.P University of Agriculture \& Technology, \\ Meerut-250110, U.P, India \\ *Corresponding author
}

\section{A B S T R A C T}

\section{Keywords}

Zinc Oxide

Nanoparticles,

Catharanthus

roseus, Green

Synthesis,

Seed germination,

Seedling growth

Article Info

Accepted:

05 April 2020

Available Online:

10 May 2020

\begin{abstract}
In present study, Zinc Oxide nanoparticles (ZnO NPs) were synthesized from leaf extract of Catharanthus roseus by green synthesis method. The synthesized nanoparticles were characterized by UV-visible spectrophotometry and Dynamic light spectroscopy (DLS) that showed the synthesis of nanoparticles of average size $385 \mathrm{~nm}$. To evaluate the effect of $\mathrm{ZnO}$ NPs on seed germination, various concentrations of nanoparticles (20, 50 and 100 ppm) were used for the treatment of wheat seed but there was not observed any significant effect on germination percentage, speed of germination and mean germination time. However, root length, shoot length, seedling length, root dry weight, shoot dry weight, seedling dry weight and seed vigour index (I and II) showed a significant increase at 50 ppm. Further, by increasing the concentration of ZnO NPs (at 100 ppm), a decrease was observed in all parameters which stipulated the toxicity of synthesized nanoparticles at higher concentration. Thus, the results of this study demonstrated that Catharanthus roseus leaf can be used as a good source for green synthesis of $\mathrm{ZnO}$ NPs and the treatment of $\mathrm{ZnO}$ NPs influenced the seedling growth and Seed vigour index significantly.
\end{abstract}

\section{Introduction}

Zinc $(\mathrm{Zn})$ is an essential micronutrient for all living organism (Laware and Raskar, 2014). In plants, it is necessary or protein synthesis, sugar formation, phytohormone synthesis (e.g. auxin), membrane function, seedling vigor, photosynthesis and also for providing protection from biotic and abiotic stress (Laware and Raskar, 2014). Thus, Zn deficiency in plant causes reduced leaf size, leaf narcosis, stunted growth and decreased seed vigor with low yield (Elhajand Unrine 2018).Besides these effects, a significant role of $\mathrm{Zn}$ in seed germination and field establishment of seedlings has been observed 
in previous literatures (Yilmaz et al., 1998; Rengel and Graham,1995; Cakmak, 2000; Marschner, 1995). In India, soil has 36.5\%Zn deficiency and it is likely to increase approximately $\quad \sim 63 \%$ by 2025 (http://zinc.org.in/zinc-uses/zinc-in-crops/) if current trend of $\mathrm{Zn}$ losses continue.

Cereals crops that are predominant food of Indian population specially wheat, have inherently low $\mathrm{Zn}$ concentration, and the cultivation of this crop in $\mathrm{Zn}$ deficient soil further decreases $\mathrm{Zn}$ content in grains (Das $e t$ al., 2019) which ultimately cause the $\mathrm{Zn}$ deficiency in human. $\mathrm{Zn}$ has significant role in reproduction, development and immunity, and $\mathrm{Zn}$ deficiency causes diarrhea, stunted growth and immunological disorder in human (Deshpande et al., 2017). It has been estimated that around $26 \%$ of the Indian population is deficient in $\mathrm{Zn}$ (http://zinc.org.in/zinc-uses/zinc-incrops/).Worldwide, more than 2 billion people are lacking in $\mathrm{Zn}$ and 800,000 people die annually due to $\mathrm{Zn}$ deficiency (http://zinc.org.in/sustainability/).

To eliminate $\mathrm{Zn}$ deficiency from wheat plants, different strategies are used. Soil application of $\mathrm{Zn}$ fertilizer is a simple and effective approach that has been extensively used to exclude the $\mathrm{Zn}$ deficiency in soil (Kutman et $a l ., 2010)$ However, it is associated with some problems. The bioavailability of $\mathrm{Zn}$ in soil or absorption of $\mathrm{Zn}$ by the plant from the soil depends on different soil properties such as salinity, high $\mathrm{pH}$ and calcareous nature of soil. The poor soil properties (high $\mathrm{pH}$, salinity, and calcareous nature of soil) lead to formation of insoluble $\mathrm{Zn}$ salt that makes it unavailable to the plants (Alloway, 2009). As, micronutrient is required in very low amount and also absorbed in very small quantity by the plant so the excessive use of fertilizers is wasted that increases the production cost of crop and also leads to loss of soil fertility.
Further, the redundant use of fertilizer also causes the environmental pollution due to wash out by rain that contaminates the ground water and rivers (Deshpande et al., 2017). Thus, bioavailability of $\mathrm{Zn}$ in soil, excessive use of $\mathrm{Zn}$ fertilizer and environmental pollution are still challenges which are need to resolve by using a more potent strategy. Currently, applications of Zinc oxide nanoparticles ( $\mathrm{ZnO}$ NPs)in agriculture are being extensively explore to resolve the problems associated with traditionally used chemical fertilizer. The positive effect of $\mathrm{ZnO}$ NPs has been estimated on plant growth and yield in many previous studies (Munir et al., 2018; Mahajan et al., 2011; Rameshraddy et al., 2017; Du et al., 2011) due to their controllable physical, chemical and biological properties. Besides growth and yield, the effect of $\mathrm{ZnO}$ NPs for influencing seed germination has also been documented in previous studies (Maity et al., 2018; Raskar and Laware, 2014; Awasthi et al., 2017; Solanki and Laura 2018; Prom-u-Thai et al., 2012).

In present study $\mathrm{ZnO}$ NPs has been synthesized from Catharanthus roseus by using green synthesis method. The nanoparticles synthesized by using this method are less toxic, cost effective and uniform in size because it does not require any toxic chemicals, high temperature, pressure (Savithramma et al., 2011; Bhumi and Savithramma,2014), and also does not produce hazardous byproduct (El-Nour et al., 2010; Stan et al., 2015) that is very common in physical and chemical methods. Further, Catharanthus roseus is an evergreen plant contains 200 terpenoid based indole alkaloids in stem, roots and leaves (Bhumi and Savithramma, 2014). It also contains secondary metabolites like vincristine, serpentine, vinblastine, ajmalicine, phenolic compounds (Gupta et al., 2018). Therefore, the leaf extract of this plant can be used as a 
reducing material and surface stabilizing agent to synthesize $\mathrm{ZnO}$ NPs (Bhumi and Savithramma, 2014). The synthesized nanoparticles were analyzed by DLS and UVspectroscopy and further studied to evaluate the effect on seed germination and seedling growth.

\section{Materials and Methods}

Zinc acetate dehydrate, Sodium hydroxide, Ethanol, Whatman No. 1 Filter paper were purchased from Hi-Media, Mumbai. All chemicals used in the experiments were analytical grade.

\section{Preparation of periwinkle (Catharanthus roseus) leaf extract}

Fresh and healthy leaves of Periwinkle (Catharanthus roseus) were taken and washed with running water followed by 4-5 times wash with double distilled water. The dried leaves were crushed in mortar and pestle to obtain fine powder. Subsequently, the fine powder $(10 \mathrm{gm})$ of cursed leaves were heated at $65{ }^{\circ} \mathrm{C}$ in a water bath for 30 minutes in 100 $\mathrm{ml}$ of double distilled water until the colour was not changed into yellow. After cooling, the leaf extract was filtered by using Whatman no.1 filter paper and the filtrate was stored at $4{ }^{\circ} \mathrm{C}$ in a refrigerator for further use.

\section{Synthesis of ZnONPs from leaf extract}

$\mathrm{ZnO}$ NPs were synthesized according to the previous studies (Bhumi and Savithramma, 2014; Gupta et al., 2018). Firstly, 0.02 M Zinc acetate dehydrate solution was prepared by adding $0.35 \mathrm{gm}$ Zinc acetate didydrate $\left(\mathrm{Zn}\left(\mathrm{CH}_{3} \mathrm{COO}\right)_{2} \cdot 2 \mathrm{H}_{2} \mathrm{O}\right)$ in $80 \mathrm{ml}$ distilled water in a conical flask. The leaf extract (20 ml) was added into Zinc acetate dehydrate solution by drop wise at $70{ }^{\circ} \mathrm{C}$ under stirring condition. The stirring was done until the precipitate was not formed which took around
2 hours. During the experiment, the $\mathrm{pH}$ was maintained 12 by using $2 \mathrm{M} \mathrm{NaOH}$. The precipitate was centrifuged at $10,000 \mathrm{rpm}$ for 10 minutes at $4^{\circ} \mathrm{C}$ and then it was washed two times with double distilled water followed by two times wash with ethanol to remove the impurities. After washing, the precipitate was collected and dried in an oven at $60^{\circ} \mathrm{C}$ overnight which formed pale yellow colour ZnO NPs.

\section{Characterization of $\mathrm{ZnONPs}$}

\section{UV-visible spectrophotometry}

The synthesized $\mathrm{ZnO}$ NPs was observed under UV-visible spectrophotometer (GENESYS 10S UV-Vis Spectrophotometer by Thermofisher Scientific). A solution of 100 ppm of ZnO NPs was prepared in double distilled water and it was observed under UVvisible spectrophotometer after ultrasonication $(100 \mathrm{~W}, 40 \mathrm{KHz})$ for 30 minutes. The absorption spectrum was recorded between 250-500 $\mathrm{nm}$ wavelengths. The double distilled water was used as blank.

\section{Dynamic light scattering (DLS)}

The particle size distribution of the ZnONPs was determined by DLS (Malvern NanoZS90). Synthesized ZnO NPs was added in double distilled water to make $100 \mathrm{ppm}$ solution followed by ultrasonication at 40 $\mathrm{KHz}$ frequency. Then, $2 \mathrm{ml}$ solution was placed in a cuvette and observed under DLS to determine the size of NPs. A constant temperature of $25^{\circ} \mathrm{C}$ was maintained for the sample holder.

\section{Germination experiment}

Germination experiment was carried out according to the previous studies (Awasthi et al., 2017; Solanki and Laura, 2018). To perform the seed germination experiment, 
different concentrations of ZnO NPs (20 ppm, $50 \mathrm{ppm}$ and $100 \mathrm{ppm}$ ) were prepared by adding the required amount of NPs in double distilled water. Healthy and uniform size seeds of WH 1105 wheat variety were taken and soaked in respective concentrations of NPs solutions. For control treatments, some seeds were soaked in distilled water. Soaking was done for 4 hours. The seeds were treated with a little amount of thiram to avoid fungal infections.

Petridishes of $15 \mathrm{~cm}$ were washed and 2 layers of towel papers were placed at the bottom and moistened. In each petridish, 50 seeds were placed at equi-distance from each other and radical end of seeds oriented downwards. Then, the petridishes were covered with the lid and kept in an incubator at $22.5 \pm 1{ }^{\circ} \mathrm{C}$ for 7 days.

Water was poured every day to keep the optimum moisture level. The experiments were performed in triplicate and Completely Randomized Design (CRD) was used to analyze the results. The following parameters were recorded after germination experiments.

\section{Germination percentage}

The number of seeds germinated was counted daily. Healthy and well-developed seedlings with complete structures were considered during counting. Germination studies were performed according to the method recommended by the Association of Official Seed Analytics (AOSA, 1998) up to 7 days. A seed was considered to germinate having radical length at least $2 \mathrm{~mm}$. The evaluation was done on the final day and was calculated as:

$$
\text { GerminationPercentage }=\frac{\text { No. of seeds produced normal seedlings }}{\text { No. of seeds set for germination }} \times 100
$$

\section{Speed of germination}

Total number of germinated seeds was counted every day from initial day to the final day. It is also called Germination Index, and was studied on the basis of the method recommended by the Association of Official Seed Analytics (AOSA, 1983).The following formula is used to calculate the speed of germination.

Speed of Germination $=\frac{\text { No. of seedling }}{\text { Day of first count }}+\ldots \ldots \ldots \ldots \ldots \ldots . . . .+\frac{\text { No. of seedling }}{\text { Day of final count }}$

\section{Mean germination time}

After the completion of the germination test period, the mean germination time was calculated on the basis of a formula given by Bonner (1983).

$$
\text { Mean Germination Time }=\frac{\sum(\mathrm{n} \times \mathrm{di})}{\text { No. of seeds sown }}
$$

Root length, shoot length and seedling length

Five seedlings were randomly selected from each petridish on the final day. The root length and shoot length were measured from the base to the tip. The mean root length shoot length were calculated and expressed in centimeter $(\mathrm{cm})$. The seedling length was calculated by adding root length and shoot length.

\section{Root dry weight, shoot dry weight and seedling dry weight}

To calculate root dry weight and shoot dry weight five seedling were randomly selected from each petridish on the final day. The roots from the base of each seedling were separated and packed in a paper bag. Subsequently, the paper bag was kept in a hot air oven at $65^{\circ} \mathrm{C}$ for complete drying. 
Mean root dry weight was calculated by dividing total dry weight with the number of seedlings. It was expressed in milligram $(\mathrm{mg})$. Same method was used to calculate shoot dry weight. Seedling dry weight was calculated by adding root dry weight and shoot dry weight.

\section{Seed vigour index-I}

It was calculated by multiplying germination percentage and seedling length.

SVI- I= Germination $\% \times$ Seedling length

\section{Seed vigour index-II}

It was calculated by multiplying germination percentage and seedling dry weight

SVI- II $=$ Germination $\% \times$ Seedling dry weight

\section{Statistical analysis}

All the data of each parameter in all experiments were subjected to statistical analysis using Completely Randomized Design in OPSTAT statistical program developed by O.P. Sheoran, Associate Professor, CCSHAU, Hisar.

\section{Results and Discussion}

\section{Green synthesis of $\mathrm{ZnO}$ NPs}

Nanoparticles synthesis of $\mathrm{ZnO}$ by using periwinkle (Catharanthus roseus) leaves has been shown in Fig.1 (a-f). The leaf extract of Catharanthus roseus contains high amount of secondary metabolites like serpentine, vincristine, ajmalicine, alkaloids, phenolic compounds etc.

These secondary metabolites act as reducing agent, stabilizing agent as well as capping agent for the synthesis of ZnO NPs (Gupta et al., 2018). Hence, Catharanthus roseus found be a good source for synthesis of ZnO NPs.

\section{Characterization of synthesized ZnO NPs}

\section{UV-visible spectrophotometry}

UV-visible spectrophotometry analysis was carried out to determine the synthesis of $\mathrm{ZnO}$ NPs. A graph was plotted by taking wavelength from $250 \mathrm{~nm}$ to $500 \mathrm{~nm}$ on $\mathrm{X}$-axis and absorbance on Y-axis. The peak absorbance was observed at $372 \mathrm{~nm}$ wavelength (Fig.2). The present finding is in accordance with findings of Gupta et al., (2018), Ghorbani et al., (2015) and Kolekar et al., (2011), which indicate the synthesis of ZnO NPs.

\section{Dynamic light scattering (DLS)}

The particle size distribution was observed by using dynamic light scattering technique. It is a common technique used for finding particle size distribution of colloidal solutions. In the particle size distribution curve, average size of synthesized $\mathrm{ZnO}$ NPs was found $385 \mathrm{~nm}$ (Fig. 3). The polydisperity index was found to be 0.259. According to Nagarajan and Kuppusamy, (2013) samples having very wide size distribution show more than 0.7 polydisperity index. However, the synthesized ZnO NPs showed less polydispersity index which indicated the uniform nature of nanoparticles.

Germination parameters (germination percentage, speed of germination and mean germination time)

Germination parameters like germination percentage, speed of germination and mean germination time are used to define the efficiency of a seed to germinate. Germination percentage is an estimate of the 
viability of a population of seeds. However, speed of germination represents the rate of seed germination during the test period. While mean germination time shows the average time period required for the seeds to germinate. There was not found any significant effect on these parameters at different concentrations of $\mathrm{ZnO}$ NPs. The data pertaining to germination percentage, speed of germination and mean germination time at different concentrations of $\mathrm{ZnO}$ NPs has been presented in Table 1.

These parameters (germination percentage, speed of germination and mean germination time) were not affected by the concentration of $\mathrm{ZnO}$ NPs because they might be mainly depend on the genetic factor. Similar result has also been observed by Rawat et al., (2018). The petriplates showing germinated seedlings at different concentration of $\mathrm{ZnO}$ NPs have been shown in Fig.4.

\section{Root length}

In the experiment, the root length of the wheat seedlings varied significantly with change in the concentration of $\mathrm{ZnO}$ NPs. The root length of control seedlings was found to be $11.57 \mathrm{~cm}$. When seed were treated with 20 ppm $\mathrm{ZnO}$ NPs, there was not found so much change in the root length. However, seed priming with $50 \mathrm{ppm} \mathrm{ZnO}$ NPs caused a significant increase in the root length i.e., 14.6 $\mathrm{cm}$, which was $26.23 \%$ more than the control.

Effect of $100 \mathrm{ppm} \mathrm{ZnO}$ NPs priming was statistically at par with that of $50 \mathrm{ppm}$. When seeds were treated with 100ppm ZnO NPs concentration, a decrease was observed in root length that was possibly due to the toxicity of nanoparticles at higher concentration. The data of root length of seedling after priming with $\mathrm{ZnO}$ NPs has been shown in Table 2.

\section{Shoot length}

In this experiment, the shoot length of control seeds (without any treatment of $\mathrm{ZnO}$ NPs) was found $8.2 \mathrm{~cm}$. The significant increase in seedling shoot length was observed in all concentrations of $\mathrm{ZnO}$ NPs $(20 \mathrm{ppm}, 50 \mathrm{ppm}$ as well as $100 \mathrm{ppm})$.The data of shoot length has been represented in Table 2. In 20 ppm treatment, shoot length was obtained e 10.33 $\mathrm{cm}$, which was $26 \%$ higher than the control seedlings. Highest shoot length was observed in $50 \mathrm{ppm} \mathrm{ZnO}$ NPs treatment that was 11.63 $\mathrm{cm}$ (41.87\% higher as compared to the control seedlings). Further increase in concentration of $\mathrm{ZnO}$ NPs caused decrease of shoot length showing possible toxicity of $\mathrm{ZnO}$ NPs.

\section{Seedling length}

The seedling length at different concentrations of $\mathrm{ZnO}$ NPs has also been shown in Table 2. The data revealed that the seedling length was also found significantly different at different concentrations of $\mathrm{ZnO}$ NPs. The length of control seedling was observed $19.77 \mathrm{~cm}$. After treatment with 20 ppm concentration of $\mathrm{ZnO}$ NPs showed 22.1 $\mathrm{cm}$ seedling length which was $11.81 \%$ higher than the control ones and was statistically at par with 100 ppm treatment. The highest seedling length was observed at $50 \mathrm{ppm}$ concentration of $\mathrm{ZnO}$ NPs that was found $26.23 \mathrm{~cm}$ and $32.72 \%$ higher than the control seedlings. The seedling length at different concentration has been shown in Fig. 5.

The increase in seedling length might be due to the production of auxin in the seedling (Zhao, 2010; Liu et al., 2013) because Zinc act as the precursor for synthesis of auxin. After the treatment of different concentrations of the ZnONPs, a sufficient amount of Zinc was available for auxin synthesis to enhance the length of the seedling. 
However, the higher concentration of NPs might lead to toxicity which retarded metabolism of embryo cells, and hence a decrease was observed in length of root, shoot and the whole seedling. Previously, Prasad et al., (2012), Lin and Xing (2007) and Maity et al., (2018) also observed the similar effect of $\mathrm{ZnO}$ NPs during seed germination.

\section{Root dry weight}

In the experiment, a significant increase in root dry weight was obtained at $50 \mathrm{ppm}$ concentration of $\mathrm{ZnO}$ NPs. The control seedling had $8.1 \mathrm{mg}$ root dry weight. After the treatment of $50 \mathrm{ppm} \mathrm{ZnO}$ NPs, highest root dry weight was observed i.e., $10.23 \mathrm{mg}$ which was $26.34 \%$ higher than the control seedlings.

The $20 \mathrm{ppm}$ and $100 \mathrm{ppm}$ treatments showed $8.2 \mathrm{mg}$ and $9.17 \mathrm{mg}$ root dry weight respectively that were not significantly different from the control one. The data related to the dry weight of roots at different concentrations of $\mathrm{ZnO}$ NPs treatment has been shown in Table 3 .

\section{Shoot dry weight}

The shoot dry weight varied significantly with change in the concentrations of $\mathrm{ZnO}$ NPs. The data has been represented in Table 3. The shoot dry weight was observed $8.57 \mathrm{mg}$ in case of the control seedlings. After $20 \mathrm{ppm}$ treatment, the dry weight of shoots was found $10.8 \mathrm{mg}$ which was $26 \%$ higher as compared to control seedlings while $42.42 \%$ increase was observed at $50 \mathrm{ppm}$ treatments.

Further, the dry weight of shoot was decreased with increase the concentration of $\mathrm{ZnO}$ NPs, and $100 \mathrm{ppm}$ concentration showed a reduction in the dry weight of shoot which was $10.67 \mathrm{mg}$ and was statistically at par with the $20 \mathrm{ppm}$ treatment of $\mathrm{ZnO}$ NPs.

\section{Seedling dry weight}

The seedling dry weight was calculated by adding root and shoot dry weight. The experiment showed significant difference in seedling dry weight with change in the concentration of $\mathrm{ZnO}$ NPs (Table 3). The seedling dry weight was observed $16.67 \mathrm{mg}$ in case of the ZnO NPs free seedlings. The seedling dry weight was increased with increase the concentration of $\mathrm{ZnO}$ NPs upto $50 \mathrm{ppm}$. It was increased by $14 \%$ and 34.61 $\%$ as compared to control seedling dry weight at $20 \mathrm{ppm}$ and $50 \mathrm{ppm}$ treatments respectively. But, at $100 \mathrm{ppm} \mathrm{ZnO}$ NPs concentration, the dry weight of seedling was reduced that indicated possible toxicity of $\mathrm{ZnO}$ NPs in the seedling at this concentration.

The seedlings dry weight showed a pattern similar to seedling length (at $50 \mathrm{ppm} \mathrm{ZnO}$ NPs, maximum seedling dry weight was observed). Similar pattern was also observed in case of dry weight of root and shoot. Comparable results have also been observed by Raskarand Laware (2014), Solanki and Laura (2018) and Narendhran et al., (2016) in previous studies.

\section{Seed vigour index (I and II)}

Seed vigour is the activity and performance of the seed during germination and seedling emergence. The data related to seed vigour index-I and II have been shown in Table 4. Seed vigour index-I calculate germination percentage and seedling growth (on the basis of length). On the other hand, Seed vigour index -II estimate germination percentage and seedling growth (on the basis of seedling dry weight).

In this experiment significant variation in the SVI-I was noted with change in the ZnO NPs concentration. In the control seedlings, SVI-I was observed 1857. 
Table.1 Germination percentage, speed of germination and mean germination time of seed treated with different concentrations of $\mathrm{ZnO}$ NPs

\begin{tabular}{|l|c|c|c|}
\hline $\begin{array}{l}\text { Concentration of } \\
\text { ZnO NPs (ppm) }\end{array}$ & $\begin{array}{c}\text { Germination } \\
\text { percentage }\end{array}$ & $\begin{array}{c}\text { Speed of } \\
\text { germination }\end{array}$ & $\begin{array}{c}\text { Mean germination } \\
\text { time (days) }\end{array}$ \\
\hline $\mathbf{0}$ & 94.00 & 14.77 & 3.17 \\
\hline $\mathbf{2 0}$ & 96.00 & 15.35 & 3.21 \\
\hline $\mathbf{5 0}$ & 99.33 & 16.28 & 3.26 \\
\hline $\mathbf{1 0 0}$ & 98.67 & 15.84 & 3.31 \\
\hline SE \pm & 1.37 & 0.36 & 0.09 \\
\hline $\mathbf{C D}(\mathbf{5 \%})$ & $\mathrm{NS}$ & $\mathrm{NS}$ & $\mathrm{NS}$ \\
\hline
\end{tabular}

Table.2 Length of root, shoot and seedling treated at different concentrations of ZnO NPs

\begin{tabular}{|c|c|c|c|}
\hline $\begin{array}{l}\text { Concentration of } \\
\text { ZnO NPs (ppm) }\end{array}$ & Root length (cm) & Shoot length $(\mathrm{cm})$ & Seedling length $(\mathrm{cm})$ \\
\hline $\mathbf{0}$ & 11.57 & 8.20 & 19.77 \\
\hline 20 & 11.77 & 10.33 & 22.10 \\
\hline 50 & 14.60 & 11.63 & 26.23 \\
\hline 100 & 13.00 & 10.17 & 23.17 \\
\hline $\mathrm{SE} \pm$ & 0.68 & 0.41 & 0.70 \\
\hline CD (5\%) & 2.26 & 1.37 & 2.31 \\
\hline
\end{tabular}

Table.3 Dry weight of root, shoot and seedling treated with different concentrations of ZnO NPs

\begin{tabular}{|c|c|c|c|}
\hline $\begin{array}{l}\text { Concentration of } \\
\text { ZnO NPs (ppm) }\end{array}$ & $\begin{array}{l}\text { Root dry } \\
\text { weight (mg) }\end{array}$ & Shoot dry weight (mg) & $\begin{array}{l}\text { Seedling dry weight } \\
\text { (mg) }\end{array}$ \\
\hline $\mathbf{0}$ & 8.10 & 8.57 & 16.67 \\
\hline 20 & 8.20 & 10.80 & 19.00 \\
\hline 50 & 10.23 & 12.20 & 22.43 \\
\hline 100 & 9.17 & 10.67 & 19.83 \\
\hline $\mathrm{SE} \pm$ & 0.46 & 0.44 & 0.56 \\
\hline CD $(5 \%)$ & 1.54 & 1.47 & 1.84 \\
\hline
\end{tabular}

Table.4 Seed Vigour Index-I and Seed Vigour Index-II of seedlings treated with different concentrations of $\mathrm{ZnO}$ NPs

\begin{tabular}{|l|c|c|}
\hline Concentration of ZnO NPs (ppm) & Seed Vigour Index- I & Seed Vigour Index- II \\
\hline $\mathbf{0}$ & 1857 & 1566 \\
\hline $\mathbf{2 0}$ & 2123 & 1825 \\
\hline $\mathbf{5 0}$ & 2605 & 2228 \\
\hline $\mathbf{1 0 0}$ & 2286 & 1957 \\
\hline SEm $\mathbf{1 5}$ & 72.59 & 58.49 \\
\hline $\mathbf{C D}(\mathbf{5})$ & 240.42 & 193.72 \\
\hline
\end{tabular}



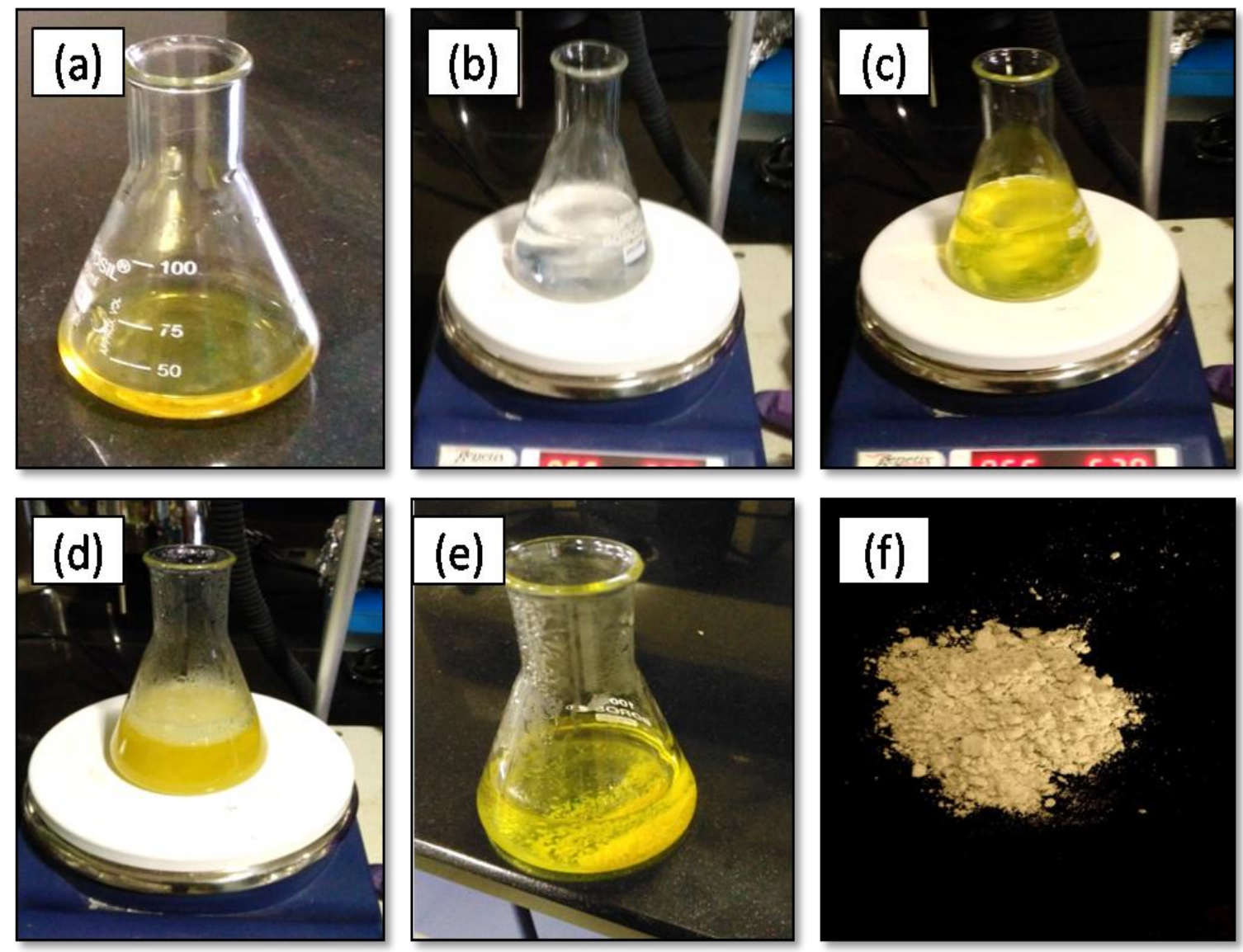

Fig. 1 Synthesis of ZnO NPs: (a) Prepared leaf extract; (b) Prepared $0.02 \mathrm{M}$ zinc acetate dehydrate solution; (c) Leaf extract added to zinc acetate dihydrate; (d) Colloidal appearance after 2 hours of stirring; (e) Precipitate of ZnO NPs; (f) ZnO NPs powder formed after oven drying of precipitate

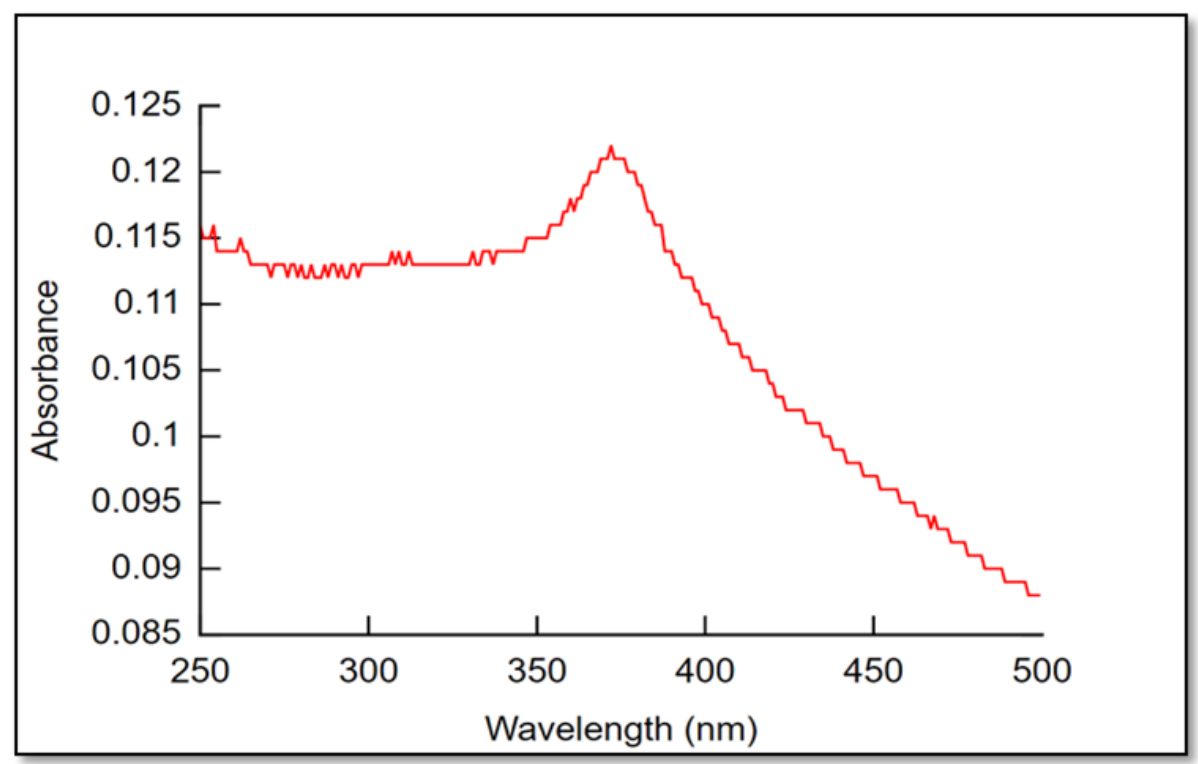

Fig.2 UV-visible spectrophotometry of synthesized ZnO NPs 


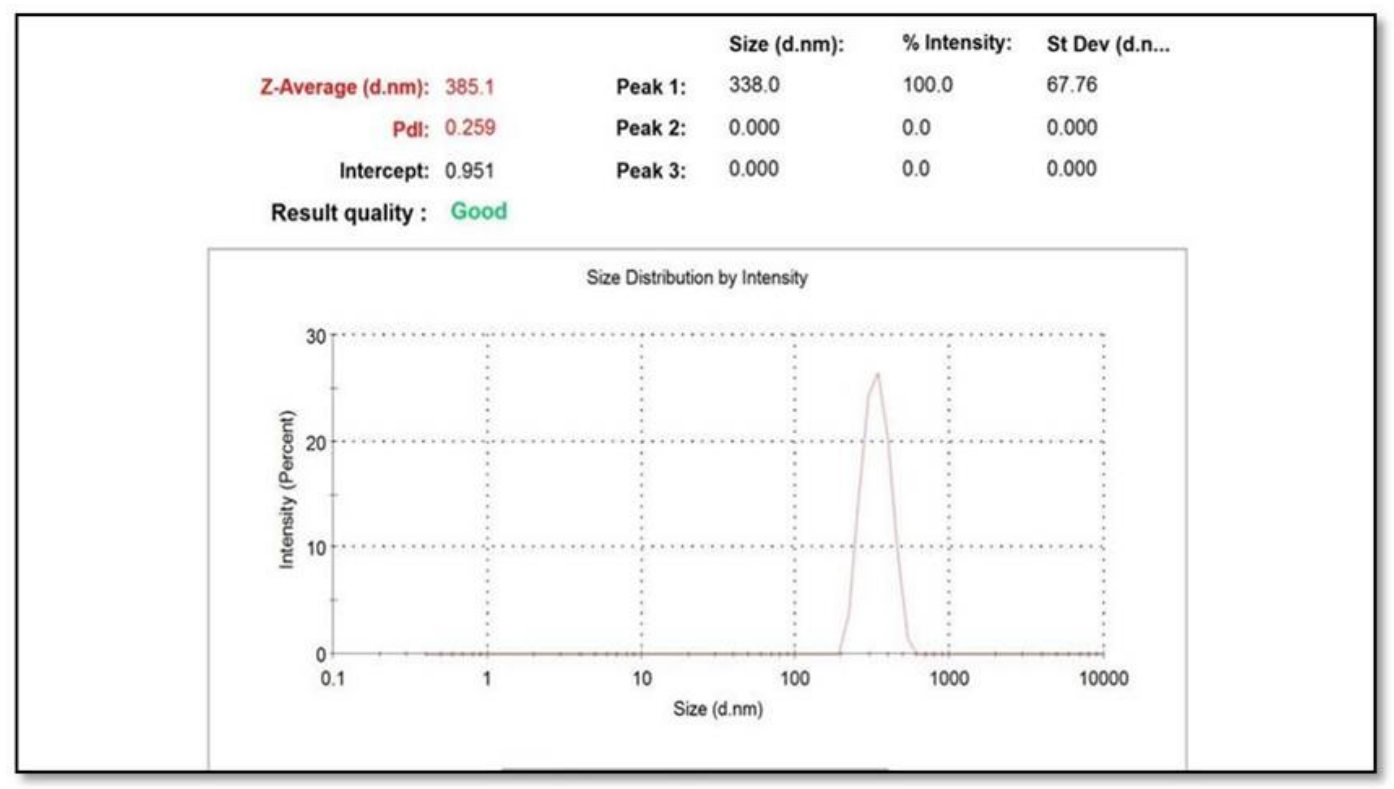

Fig.3 Dynamic light Scattering of Synthesized ZnO NPs
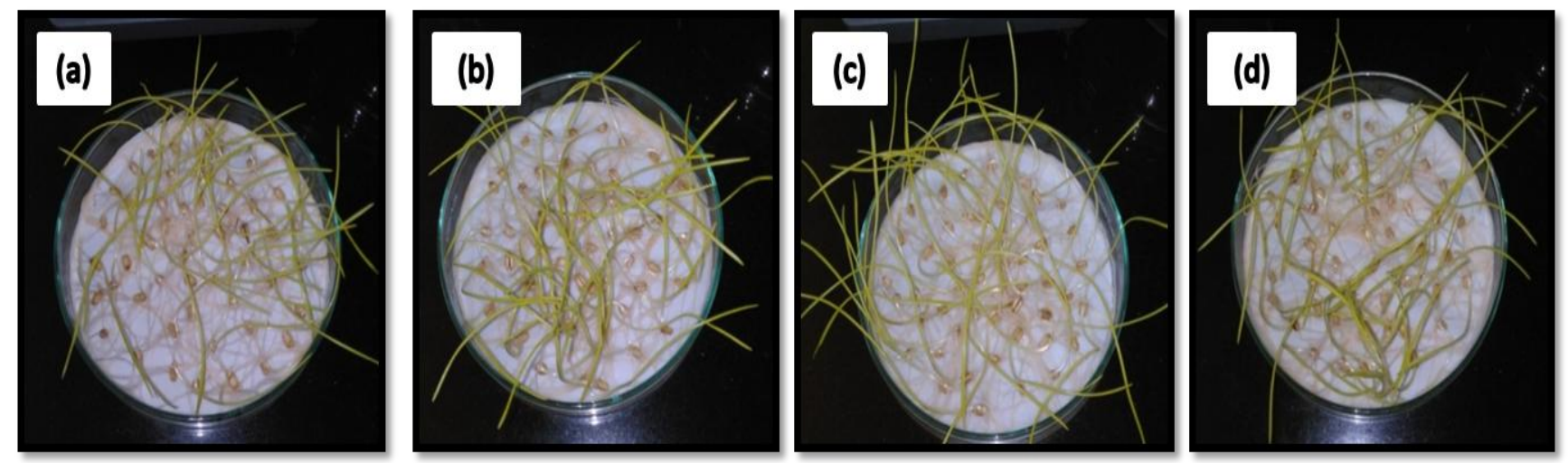

Fig.4 Petriplates containing seedlings treated with different concentrations of ZnO NPs; (a) 0 ppm; (b) 20 ppm; (c) 50 ppm; (d) 100 ppm
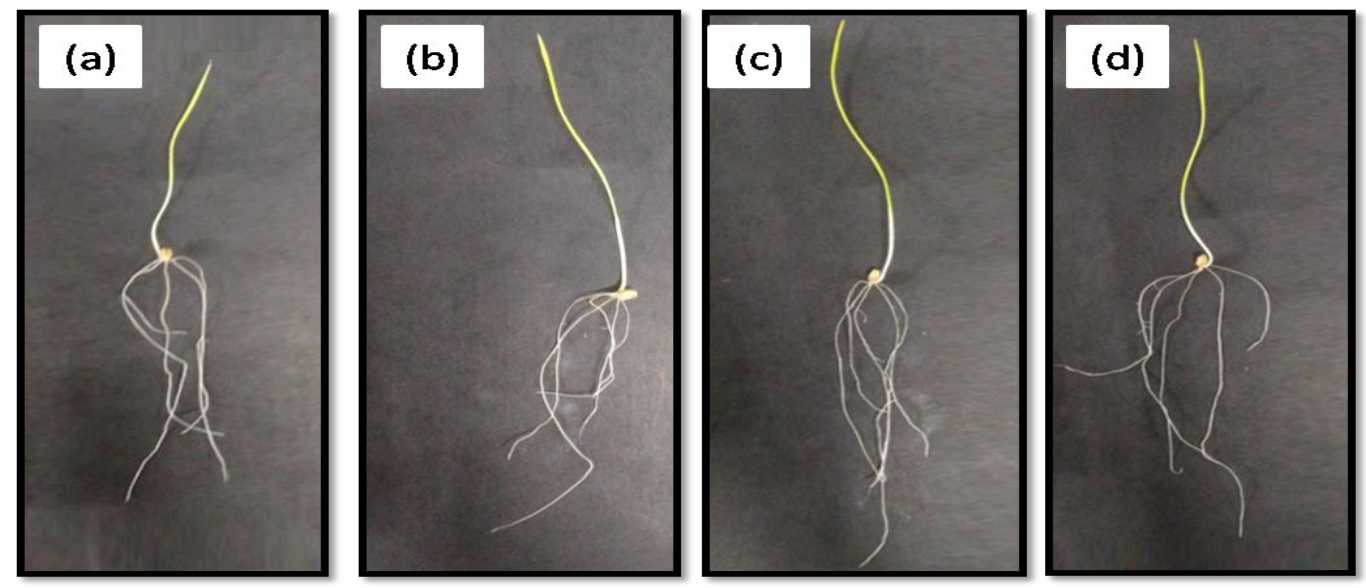

Fig.5 Seedlings of wheat treated with different concentrations of ZnO NPs; (a) 0 ppm;

(b) 20 ppm; (c) 50 ppm; (d) 100 ppm 
While after $20 \mathrm{ppm} \mathrm{ZnO}$ NPs treatment, significant increase was found that was 14.31 $\%$ higher than the control seedling. Highest SVI-I was observed at $50 \mathrm{ppm} \mathrm{ZnO} \mathrm{NPs}$ treatment with $40.28 \%$ increased as compared to the control seedlings. However, after100 ppm ZnO NPs treatment, the SVI-I was significantly lower than the $50 \mathrm{ppm}$ treated seedlings which showed possible toxicity of $\mathrm{ZnO}$ NPs at concentration higher than $50 \mathrm{ppm}$. The variation in the seed vigour index-I due to concentration of $\mathrm{ZnO}$ nanoparticles might be because of the seedling length and germination percentage as seed vigour index-I is the product of seedling length and the germination percentage of the seedlings.

$\mathrm{ZnO}$ NPs treatments also had a significant effect on the SVI-II of wheat (Table 4). SVIII was observed 1566 in control seedlings. After $20 \mathrm{ppm} \mathrm{ZnO}$ NPs treatment, a significant increase of $16.57 \%$ was found in SVI-II than control. Highest SVI-II was observed at $50 \mathrm{ppm} \mathrm{ZnO}$ NPs treatment, which was $42.32 \%$ higher than the control seedlings. Further, increase in concentration of $\mathrm{ZnO}$ NPs (100 ppm) decrease in SVI-II was observed. The variation in the seed vigour index-II with different concentrations of $\mathrm{ZnO}$ nanoparticles might be due to the seedling dry weight and germination percentage as seed vigour index-II is the product of seedling dry weight and the germination percentage of the seedlings. Similar results were also examined by Rawat et al., (2018).

In conclusion, $\mathrm{ZnO}$ NPs can be synthesized by using Catharanthus roseus as a reducing agent. UV-visible spectroscopy and DLS indicated the synthesis of $\mathrm{ZnO}$ NPs. Germination percentage, speed of germination and mean germination time were not found significantly influenced by the treatment of different concentrations of $\mathrm{ZnO}$ NPs.
However, a significant increase was observed in root length, shoot length, seedling length, root dry weight, shoot dry weight, seedling dry weight, seed vigour index I and seed vigour index II at different concentrations of $\mathrm{ZnO}$ NPs treatment. The maximum increase in all parameters was exhibited at $50 \mathrm{ppm}$ concentration. Further, increase in concentration (100 ppm) showed a reduction in all parameters that was possible due to the toxicity of nanoparticles at higher concentration.

\section{Acknowledgment}

Authors are thankful to Department of Biotechnology, Government of India for providing the grant to carry out the study.

\section{References}

Alloway, B. J. 2009. Soil factors associated with zinc deficiency in crops and humans. Environmental Geochemistry and Health. 31(5): 537-548.

Association of Official Seed Analysis (AOSA). 1983. Seed vigor testing handbook, Contribution No. 32 to the Handbook of seed testing. Association of official seed analysis. Springfield.

Association of Official Seed Analysis (AOSA). 1998. Rules of testing seeds. Journal of Seed Technology. 12:1-11

Awasthi, A., Bansal, S., Jangir, L.K., Awasthi, G., Awasthi, K. K. and Awasthi, K. 2017. Effect of $\mathrm{ZnO}$ nanoparticles on germination of Triticumaestivum seeds. In Macromolecular Symposia. 376(1): 1700043.

Bhumi, G., and Savithramma, N. 2014. Biological synthesis of zinc oxide nanoparticles from Catharanthus roseus (L.) G. Don. Leaf extract and validation for antibacterial activity. International Journal of Drug Development and Research. 6(1): 208214.

Cakmak, I. 2000. Possible Roles of Zinc in Protecting Plant Cells from Damage by Reactive Oxygen Species. New 
Phytology. 146: 185-205.

Das, S., Green, A., and Fan, M. X. 2019. Zinc Deficiency in Indian Soils is Associated with Low Crop Productivity and Crop Quality. Better Crops - South Asia 11-14.

Deshpande, P., Dapkekar, A., Oak, M. D., Paknikar, K. M., \&Rajwade, J. M. 2017. Zinc complexed chitosan/TPP nanoparticles: a promising micronutrient nanocarrier suited for foliar application. Carbohydrate Polymer. 165: 394-401.

Du, W., Sun, Y., Ji, R., Zhu, J., Wu, J. and Guo, H. 2011. TiO 2 and $\mathrm{ZnO}$ nanoparticles negatively affect wheat growth and soil enzyme activities in agricultural soil. Journal of Environmental Monitoring. 13(4): 822-828.

Elhaj, B., Z. and Unrine, J.M. 2018. Functionalized-ZnO-nanoparticle seed treatments to enhance growth and $\mathrm{zn}$ content of wheat (Triticumaestivum) seedlings. Journal of agricultural and food chemistry. 66(46): 12166-12178.

El-Nour, K. M. A., Eftaiha, A.A., Al-Warthan, A. and Ammar, R. A. 2010. Synthesis and applications of silver nanoparticles. Arabian Journal of Chemistry. 3(3): 135140.

Ghorbani, H. R., Mehr, F. P., Pazoki, H. and Rahmani, B. M. 2015. Synthesis of $\mathrm{ZnO}$ nanoparticles by precipitation method. Oriental Journal of Chemistry. 31(2): 1219-1221.

Gupta, M., Tomar, R. S., Kaushik, S., Mishra, R. K. and Sharma, D. 2018. Effective antimicrobial activity of green $\mathrm{ZnOnano}$ particles of Catharanthus roseus. Frontiers in microbiology. 9: 2030.

http://zinc.org.in/sustainability/

http://zinc.org.in/zinc-uses/zinc-in-crops/

Kolekar, T. V., Yadav, H. M., Bandgar, S. S. and Deshmukh, P. Y. 2011. Synthesis by solgel method and characterization of $\mathrm{ZnO}$ nanoparticles. Indian Streams Research Journal. 1(1).

Kutman, U. B., Yildiz, B., Ozturk, L. and Cakmak, I., 2010. Biofortification of durum wheat with zinc through soil and foliar applications of nitrogen. Cereal
Chemistry. 87(1): 1-9.

Laware, S. L. and Raskar, S. 2014. Influence of zinc oxide nanoparticles on growth, flowering and seed productivity in onion. International Journal of Current Microbiology and applied Science. 3(7): 874-881.

Lin, D. and Xing, B. 2007. Phytotoxicity of nanoparticles: inhibition of seed germination and root growth. Environmental Pollution. 150(2): 243-250.

Liu, X., Zhang, H., Zhao, Y., Feng, Z., Li, Q., Yang, H.Q., Luan, S., Li, J. and He, Z. H. 2013. Auxin controls seed dormancy through stimulation of abscisic acid signaling by inducing ARF-mediated $\mathrm{ABI} 3$ activation in Arabidopsis. Proceedings of the National Academy of Sciences. 110(38): 1548515490.

Mahajan, P., Dhoke, S. K. and Khanna, A. S. 2011. Effect of nano-ZnO particle suspension on growth of mung (Vignaradiata) and gram (Cicerarietinum) seedlings using plant agar method. Journal of Nanotechnology. 2011.

Maity, A., Natarajan, N., Vijay, D., Srinivasan, R., Pastor, M. and Malaviya, D. R. 2018. Influence of metal nanoparticles (NPs) on germination and yield of oat (Avena sativa) and berseem (Trifoliumalexandrinum). Proceedings of the National Academy of Sciences, India Section B: Biological Sciences. 88(2): 595-607.

Marschner, H. 1995. Mineral Nutrition of Higher Plants. (2nd Ed.) Academic Press, London. pp 889.

Munir, T., Rizwan, M., Kashif, M., Shahzad, A., Ali, S., Amin, N., Zahid, R., Alam, M.F.E. and Imran, M., 2018. Effect of zinc oxide nanoparticles on the growth and $\mathrm{Zn}$ uptake in wheat (Triticumaestivum L.) By seed priming method. Digest Journal of Nanomaterials\&Biostructures. $\quad$ 13(1): 315-323.

Nagarajan, S. and Kuppusamy, K. A. 2013. Extracellular synthesis of zinc oxide 
nanoparticle using seaweeds of gulf of Mannar, India. Journal of Nanobiotechnology. 11(1): 39.

Narendhran, S. and Sivaraj, R. 2016. Biogenic $\mathrm{ZnO}$ nanoparticles synthesized using $\mathrm{L}$. aculeata leaf extract and their antifungal activity against plant fungal pathogens. Bulletin of Materials Science. 39(1): 1-5.

Prasad, T. N. V. K. V., Sudhakar, P., Sreenivasulu, Y., Latha, P., Munaswamy, V., Reddy, K. R. and Pradeep, T. 2012. Effect of nanoscale zinc oxide particles on the germination, growth and yield of peanut. Journal of Plant Nutrition. 35(6): 905-927.

Prom- u- thai, C., Rerkasem, B., Yazici, A. and Cakmak, I. 2012. Zinc priming promotes seed germination and seedling vigor of rice. Journal of Plant Nutrition and Soil Science. 175(3): 482-488.

Rameshraddy, G. J., Pavithra, G.J., Mahesh, S., Geetha, K.N. and Shankar, A.G., 2017. Seed priming and foliar spray with nano zinc improves stress adaptability and seed zinc content without compromising seed yield in ragi (Finger millet). International Journal of Pure Applied Bioscience. 5(3): 251-258.

Raskar, S.V. and Laware, S.L., 2014. Effect of zinc oxide nanoparticles on cytology and seed germination in onion. International Journal of Current Microbiology and Applied Science.3(2): 467-473.

Rawat, P. S., Kumar, R., Ram, P. and Pandey, P. 2018. Effect of Nanoparticles on Wheat
Seed Germination and Seedling Growth. International Journal of Agricultural and Biosystems Engineering. 12(1): 13-16.

Rengel, Z. and Graham, R. D., 1995. Importance of seed $\mathrm{Zn}$ content for wheat growth on Zn-deficient soil. Plant and Soil. 173(2): 259-266.

Savithramma, N., Rao, M. L., Rukmini, K. and Devi, P. S. 2011. Antimicrobial activity of silver nanoparticles synthesized by using medicinal plants. International Journal of ChemTech Research. 3(3):1394-1402.

Solanki, P. and Laura, J. S. 2018. Effect of ZnO nanoparticles on seed germination and seedling growth in wheat (Triticumaestivum). Journal of Pharmacognosy and Phytochemistry, 7(5): 2048-2052.

Stan, M., Popa, A., Toloman, D., Dehelean, A., Lung, I. and Katona, G., 2015. Enhanced photocatalytic degradation properties of zinc oxide nanoparticles synthesized by using plant extracts. Materials Science in Semiconductor Processing. 39: 23-29.

Yilmaz, A., Ekiz, H., Gültekin, I., Torun, B., Barut, H., Karanlik, S. and Cakmak, I. 1998. Effect of seed zinc content on grain yield and zinc concentration of wheat grown in zinc- deficient calcareous soils. Journal of Plant Nutrition. 21(10): 2257-2264.

Zhao, Y. 2010. Auxin biosynthesis and its role in plant development. Annual review of plant biology. 61: 49-64.

\section{How to cite this article:}

Bhupendra Bhaskar Meher, Shivraj Sahu, Shivangi Singhal, Mayank Joshi, Poonam Maan and Sneh Gautam. 2020. Influence of Green Synthesized Zinc Oxide Nanoparticles on Seed Germination and Seedling Growth in Wheat (Triticum aestivum). Int.J.Curr.Microbiol.App.Sci. 9(05): 258-270. doi: https://doi.org/10.20546/ijcmas.2020.905.029 